\title{
Street Art and Murals as a Way of Artistic Transformation of the Environment of the Modern City
}

\author{
Marianna Maevskaya ${ }^{1, *}$ \\ ${ }^{1}$ Scientific Research Institute of Theory and History of Architecture and Urban Planning, Branch of the Central \\ Institute for Research and Design of the Ministry of Construction and Housing and Communal Services of the \\ Russian Federation, Moscow, Russia \\ "Corresponding author. Email: Marianna.maevskaya@gmail.com
}

\begin{abstract}
The article below considers different aspects of implementation of street-art practice in the contemporary city architecture. The article recognizes various placements of murals in residential and former industrial zones as a very convenient strategy of contemporary street-art for creation of a new visual image for a single building or for a whole city. Also, the work with street-art examples in different scales is considered: from single murals that cover parts of buildings to a complex of several murals that form image of the whole district. The article shows character of changes of artistic image of contemporary city depending on the various capabilities of various types of street-art technics. Like any relatively new phenomenon, street art does not yet have a proper fundamental justification in the national art history. Research in street art in most cases is a series of individual portraits of artists of this direction of public art. Much of the works about street art, both Russian-speaking and foreign, at best contain a description and fragmentary mosaic of the work of individual artists.
\end{abstract}

Keywords: Street-art, Murals, Open public space, City context, Media-technologies, Artistic image of buildings, Contemporary city.

\section{INTRODUCTION: ABOUT THE TERMINOLOGY OF MODERN STREET ART}

The talk about the recognition of street "hooliganism and ugliness" in the categories of valuable artistic expressions worthy of study and preservation, arose in modern culture not so long ago and proceeded differently in individual countries. The earliest attention to teenage graphic protests, expressed in the form of graffiti and street art, arose in the United States at the turn of the 1980s. The well-known propagandist and researcher of street art Simon Armstrong defines the beginning of the mass distribution of graffiti in the mid-1960s, first in Philadelphia, then in New York, and then around the world [1].

He also emphasizes that graffiti statements are aimed at expressing their own emotions and are often of a protest nature, meanwhile the street art statements are more often aimed at improving the environment or society as a whole, and do not carry such destructive energy as most graffiti. Perhaps that is why the spread of street art practices allowed to finally begin to perceive these artistic statements in the category of full-fledged contemporary art, gradually developed to a large-scale and quite respectable branch of modern art culture.

In this context, it can be said that graffiti is a kind of anti-art, framed through protest and destruction. Meanwhile street art was an artistic practice that converted this protest into a commodity-money relationship and partially reconciled street art with law-abiding society. The term "street art" began to come into use in the early 1990s, when various variants of such practices could already be found in different countries. Today it is a powerful international subculture with a wide range of techniques and stylistic techniques [2]. Abstract lettering and stencil street art, muralism and optical illusions, digitized videoprojecting and various figurative techniques are just 
part of the ways used by contemporary street art artists to diversify the dull urban environment. The widespread spread of the street art subculture has required many countries to enact appropriate legislation regulating various aspects of this artistic phenomenon in public space.

\section{CLASSIFICATION OF ARTISTIC TECHNIQUES TRANSFORMING URBAN PUBLIC SPACES}

The art of the 21 st century is dynamically adapting new tools and ways of artistic expression. Street art, as well as media facades and videomapping, by the 2020s have become new recognizable techniques for shaping the image of the urban environment of the digital age. The emphasis is on the cast, even grotesque, mixing of scale and violation of any familiar hierarchy of elements. Chamber scenes are placed on the giant surfaces of residential and industrial buildings, elements of urban engineering infrastructure. Figures of fairy-tale heroes and faces of ordinary people in unexpected conditions and dimensions become characters of a new visual matrix of urban space. The techniques of book and graphic design, elements of advertising and video installations are beginning to play a more important role in shaping the image of a particular place, more than the traditional architectural elements of buildings. Video projections of media facades, huge abstract panels and plot murals become new visual dominants of the environment, replacing individual images of silhouettes and facades of buildings of past eras.

Initial graffiti and the first examples of other techniques of street art had a chamber scale, but as the popularity of street art grew, the physical parameters of drawings and inscriptions steadily increased. Murals of the last decade can occupy hundreds or even thousands of square meters of building surfaces and seriously affect the imagery of the environment on a city-made scale. For example, the works of the German artist Hendrik Beikirch better known as ECB, can take up to several tens of meters. His huge black-and-white portraits are on the walls of cities in India, Sweden, Holland, Germany, and the USA. In 2012, he created a mural "Portrait of a Fisherman" with a height of 72 meters in Busan, South Korea. The following year, in the Dutch Heerlen, he continued the theme of fixing the ordinary inhabitants of the city and created a "Portrait of a Sailor" — the largest portrait image in the countries of Benelux [3]. And the work "Evolution 2" by the Russian artist Misha Most for the art festival of urban culture "Art Ovrag" [4] 2017 on the territory of the metallurgical plant in Vyksa of the Nizhny Novgorod region was included in the Guinness Book of Records as the largest continuous mural in Russia and Europe, performed by one author. The area of this composition was as big as 10,800 sq. m. [5]. Later Pokras Lampas had made even larger street-art mural for "Lokomotiv" stadium.

\section{STREET ART IN RUSSIAN CITIES}

The history of Russian street art as a fullfledged artistic phenomenon began to develop later of Western analogues, but quickly entered the world context of street art. There were several groups of enthusiasts and like-minded people in Russia, including the group of ZUK and its leader Sergey Ofseikin, Alexey Luka, Maxim Revansh, Slava PTRK, ZUCCLUB, ZMOGK (Konstantin Danilov), Misha Most. Street art was developed especially consistently not only by the artists themselves, but also by the curators of special projects, festivals and publications in the press. Already in 2000, Russian artists participated in international teams and projects on a par with foreign colleagues. And since 2010, Russia has periodically hosted representative international events in the field of street art ("Figure 1"). French artist Christian Guemi, better known as C215, created his first really large-scale mural for the Moscow International Biennale of Young Art (2010) [6]. Brazilian artist Eduardo Cobra (Kobra) depicted the great Maya Plisetskaya in his multicolored graphics on the entire wall over the square of her name in Moscow ("Figure 2"). Since the mid-2000s, not only in Moscow and St. Petersburg, but also in many other Russian cities, one-time actions have been held that popularized street art in the public consciousness. In the following decade, specialized street art shows and festivals with wide international participation began to take place regularly in Russia. 

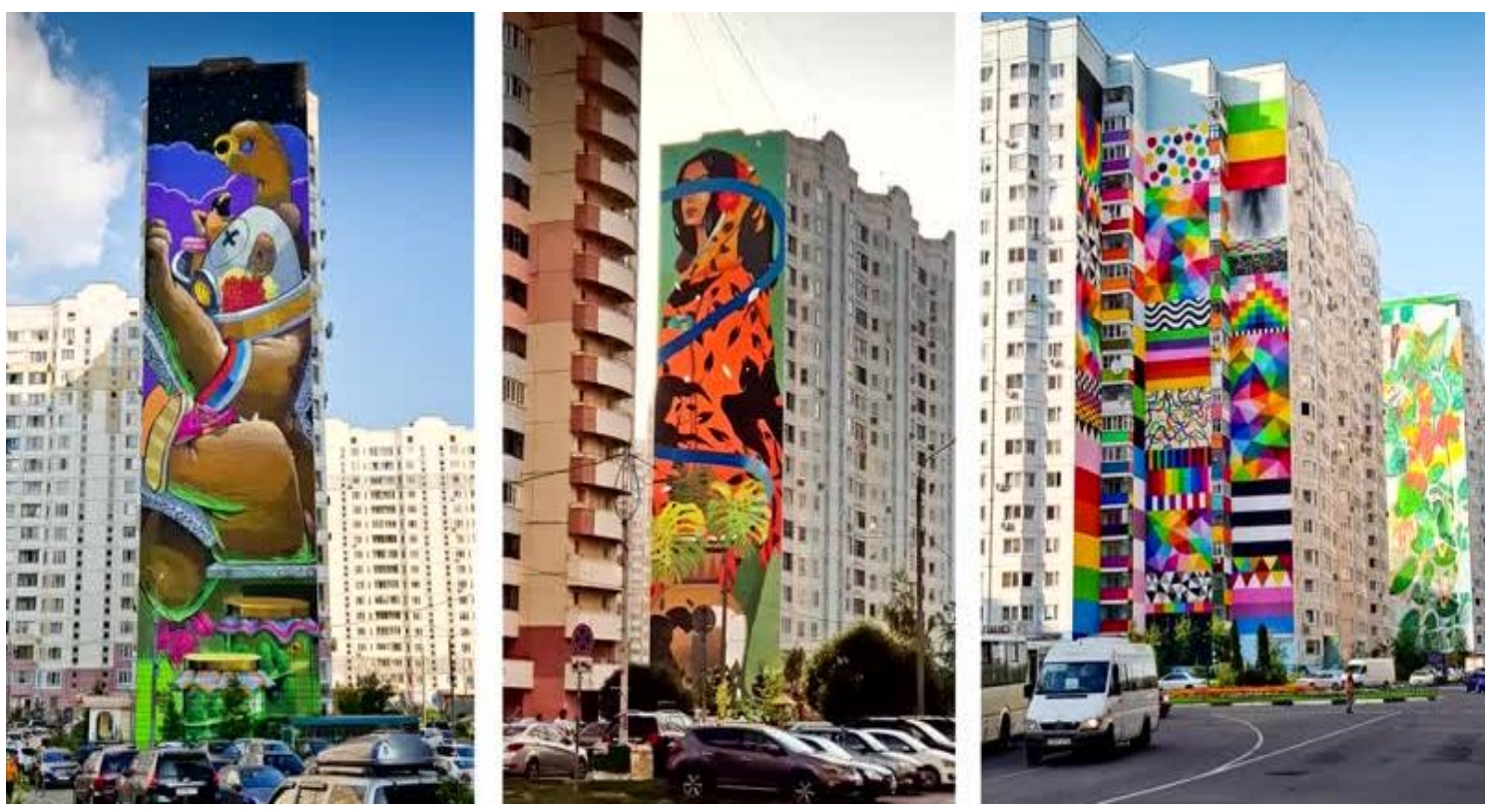

Figure 1 "Morphogenesis" street-art international fest in Odintzhovo, Moscow region, 2020.

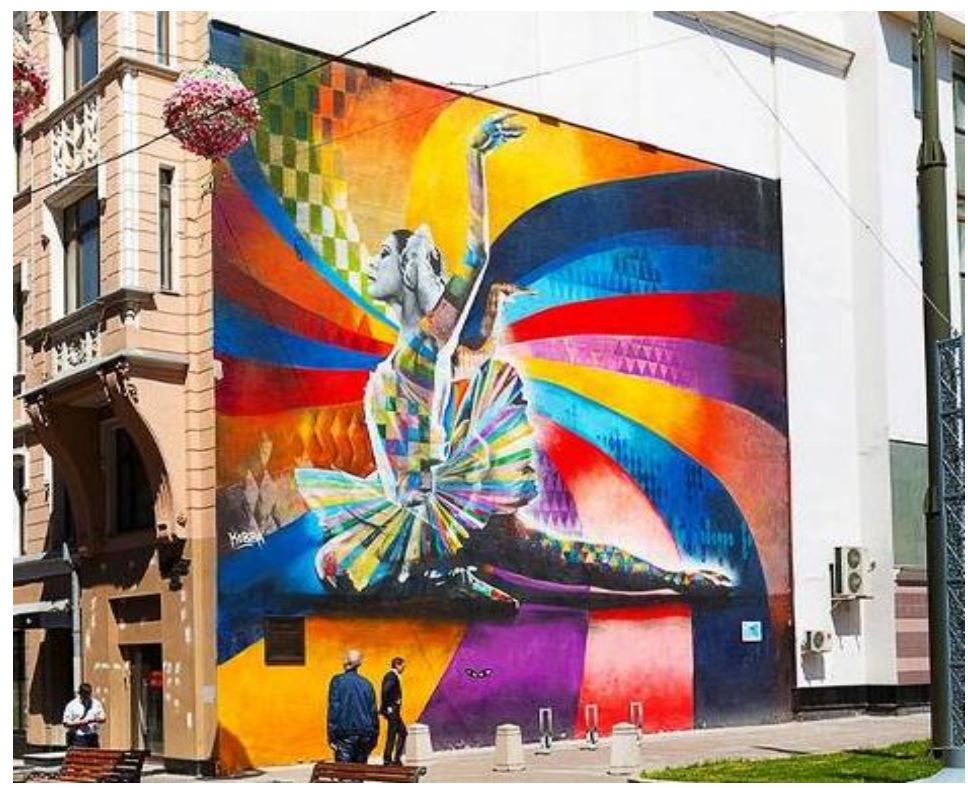

Figure 2 Eduardo Kobra. Portret of Maya Plisetskaya, Moscow, Russia, 2013.

It is significant that as a result of such efforts of certain groups of people in Russia in the 2000s and especially in the 2010s, such areas of public art as large-scale street art and murals developed very actively. Street art in this case refers to Russified versions of the graffiti subculture adapted to the local context. Moreover, murals are divided into work with the suburban areas — painting substations, auxiliary technical buildings of yards and small public spaces, as well as to work with high-rise residential buildings - murals on the nowindow sides of high-rise residential or public buildings. As a result, the scale of the works brings these works of art to the status of urban planning dominants, improves navigation in typical residential buildings and brings individualization to the urban environment.

An important element in the dissemination of aesthetically meaningful and professional street art is working with residents. As a rule, an unprepared resident does not know what he wants and how to get something interesting. The artist must find the features of a particular place and present his artistic solution that is suitable for this place. And only 
then convince the residents that this is exactly what they wanted.

There is a very wide palette of author's styles and directions in the Russian practice of street art. Many artists work in different techniques and scales. For example, in the works of Ilya Slak there is both muralism and abstract lettering (work for the "Other Space" festival). Pokras Lampas - one of the most famous and recognizable masters of domestic street art, working in the style of "calligraphy." It is widely known that the Atrium shopping center building in Kurskiy railway station square in Moscow is being individualized in 2017-2018 ("Figure 3"). Russian examples of street art more often demonstrate not so much social protest as an ironic view of reality and philosophical approach to life.[7]

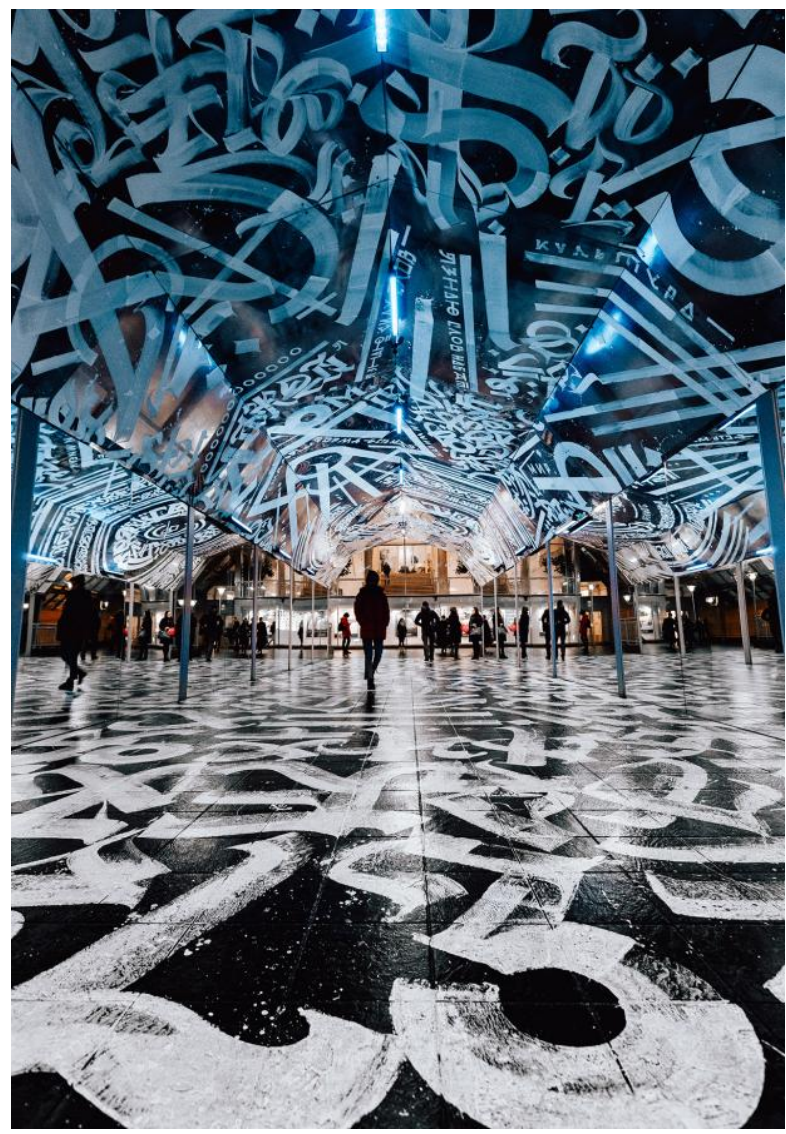

Figure 3 Pokras Lampas. underground passage on Kurskaya metro station, Moscow, Russia, 2018.

Maxim Revansh from Magnitogorsk (on the high-rises of Yekaterinburg), Alexander Demkin, Stepan Krasnov (310) noted especially large-scale murals on high-rise residential buildings. Roman Muratkin and Alexey Kislow created a spectacular work "Alice in Wonderland" in St. Petersburg for the 2014 ArtMossphere Festival. ("Figure 4") 


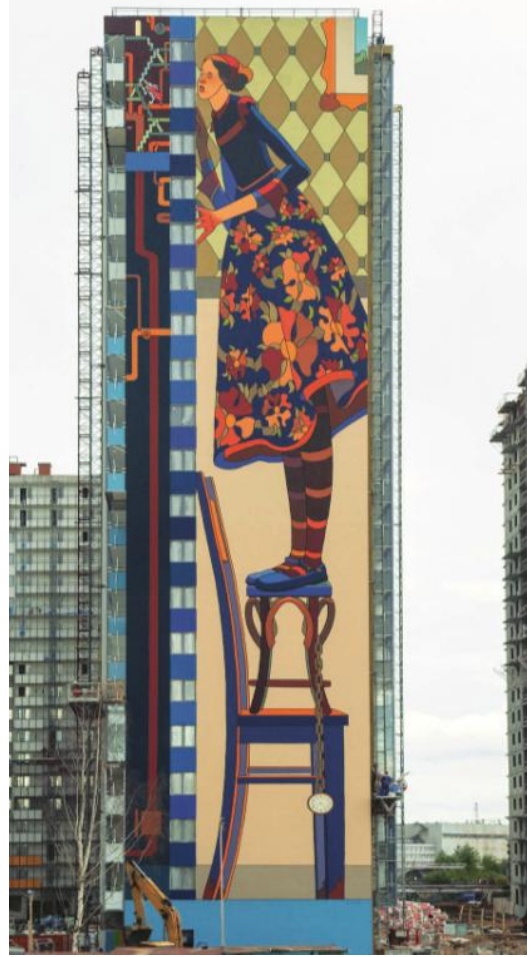

Figure 4 R.Muratkin, R.Kislow "Alice in Wonderland" in St. Petersburg, 2014.

Among street artists, many and those who being interested in street art and graffiti, received a professional art education. For example, Artem Stefanov (Stfnv) is a professional graphic designer, has a solid experience of international projects. His methods of work are optical illusions, projected video material and digitized mosaic portraits. Among the projects are one-time design of many cultural events and festivals, including works for "ARMA" 2017 in Moscow and St. Petersburg, design of the "GEM" festival in Georgia in 20162017 [8].

\section{FESTIVALS AND INTERNATIONAL PROJECTS}

Local street art festivals have been held in Russia regularly only in the last decade. And this is almost always the result of organizational initiatives of enthusiasts and artists themselves. Private sponsors, foundations and a few museums of contemporary art, as well as young art historians try to promote the positive capabilities of street art in the national social and artistic life. Interest in projects in the format of street art is gradually gaining a wider geography. In addition to both capitals, street art festivals were successfully held in Blagoveshchensk, Kazan, Nizhny Novgorod,
Novosibirsk, Ekaterinburg and many small cities. The "Cultural Code" festival of street art in Chelyabinsk in the current 2020 received a positive public response with wide coverage in the federal press. Since 2010, street art has been periodically used as a socially effective tool to change the perception of contemporary art in general by Russian citizens, usually sceptical to experiments in art in the space of the modern city. [9].

Festivals often become a notable phenomenon of urban life, involving a large number of outside observers, who are far from the problems of contemporary art, but lively reacting to the largescale visual interventions of contemporary artists in the urban environment, carried out within the framework of such festivals and artistic actions. The "Best City of the Earth" festival of 2013 in Moscow became a bright phenomenon of urban art life. The project of the creative association "ARTMOSSFERA" - the Biennale of Street Art, held regularly from 2014 to 2018, in general significantly expanded the abilities of citizens' perception of large-scale street art not only in the capital, but also as a possible model of transformation of the city - throughout Russia.

Understanding the importance of street art as an effective tool for transforming a negative urban environment helps to apply such practices to modernize and transform an entire city. A textbook example is the town of Vyksa in Nizhny Novgorod region, where since 2011 the degraded environment of the Vyksa's steelworks (city-forming enterprise) has been undergoing artistic transformation. Over the past decade, dozens of contemporary artists and graffiti artists, including Maxim Revansh, Pasha 183, Stas Bags, Marat Morik, Petro, Ilya Slak, Nootk (Vladimir Gupalov), Aber (Andrei Berger) and many other well-known representatives of the domestic street art have been featured in the Art Ovrag festival with murals and individual panels on the site and facades of the factory's workshops. Following the factory workshops, the artists expanded their interventions into the urban space and began to create murals on the ends of residential buildings.[10]

Numerous summer festivals create the most suitable conditions for the emergence of new murals and panels in open public spaces. The territory of the Moscow art cluster "Flacon" (also the former territory of the plant) every year pleases visitors with new examples of works by "street" artists. In particular, such a famous master, a veteran of Russian street art as Misha Most, whose 
works are even placed in the collection of the Tretyakov Gallery, still makes his artistic statements in open city spaces. In 2020, he exhibited his next street art composition on the "Flacon" in a very recognizable author's manner.

Ksenia Kokel, originally an academic artist from Cheboksary, is now a representative of the direction of realistic portrait street painting in urban spaces. Her name is not yet so widely known as the name of the Latin American artist El Mac, or the Frenchman C 215, or the Australian Rone, who create large-scale portrait murals in an expressive hyper-realistic manner. But this direction of street art is gaining more and more popularity. Eva Busevich successfully popularizes stencil street art among Moscow authors, ironically reacting to topical topics of society (covid, political trends like BLM). She is echoed by the artist Molly Say, creating colourful plot murals to the main themes of 2020 - to the COVID-19 and the pandemic. Alexandra Samotaeva (Timirimi), Anton Art Abstractov, Yuri Averin, Pasha 183, Sergey Akraimov work in the genre of abstraction and geometrized graphics.

\section{FEATURES OF STREET ART PRACTICES IN RUSSIA}

In all countries, the appearance of most murals is the result of the artist's contract with the authorities, as the implementation of such plans requires a lot of time, an abundance of painting materials, it is impossible without the use of additional technical means (e.g. auto-lift) and other difficulties. But in Russia, even large uncoordinated murals run the risk of being quickly destroyed by some utility workers. Therefore, enthusiasts of street art and street art spend a lot of time promoting the concepts of the positive impact of these artistic practices on the urban space, forming a proper public opinion, indirectly influencing the mood of officials.

Large-scale murals in modern Russian cities, following international trends, are most often found on three types of structures. These are either giant panels on the sides of residential buildings, including high-rise, long murals on the facades of the buildings of former factories and industrial zones, as well as street art and graffiti on the general civic elements of transport and engineering urban infrastructure - bridges, overpasses, etc.

Many contemporary artists who are consistently engaged in street art have their own recognizable manner and a set of artistic techniques that make it easy to identify the author. At the same time, the choice of style does not depend on the location of the work and the specific urban situation. It's a kind of pure art for the sake of art. ("Figure 7")

Such street art does not carry a particular protest load and does not respond to the specific social context of the place. Russian masters in this case are no exception. Many authors have a great international experience, and everywhere it is primarily a demonstration of recognizable techniques from a particular artist. ("Figure 5", "Figure 6") For example, Alexey Luka (Alexei Luchko) creates large-scale color geometric compositions, choosing for their representation the former industrial zones and surfaces of structures mainly technical purpose. Such notable works of his include a mural on the shop floor of the Vyksa Metallurgical Plant, in 2019 - a painting of a substation on the territory of the "Stankolit "Moscow business park [11].

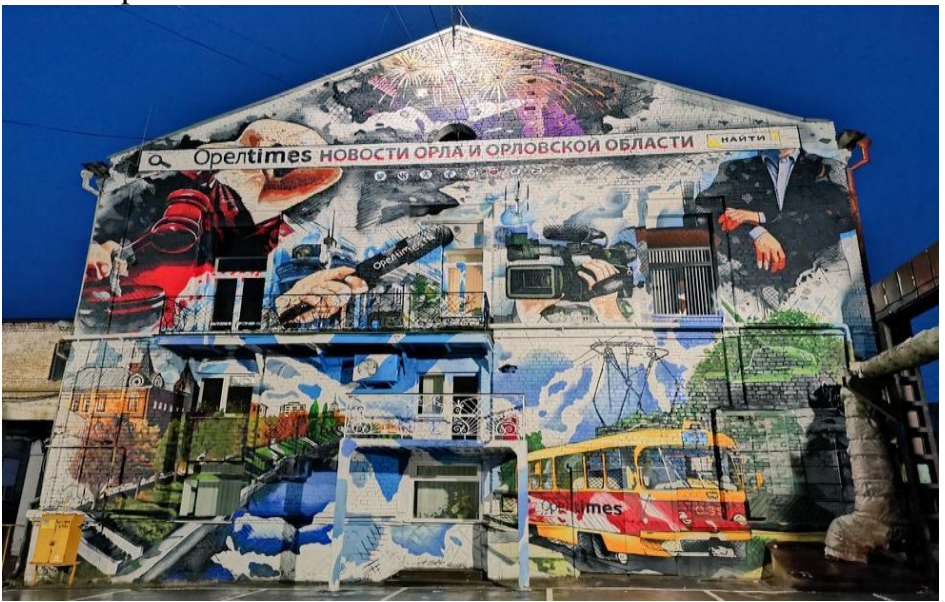

Figure 5 Vladimir Kutnikov, Polesskaya str.11, mural in Orel, Russia, 2020. 


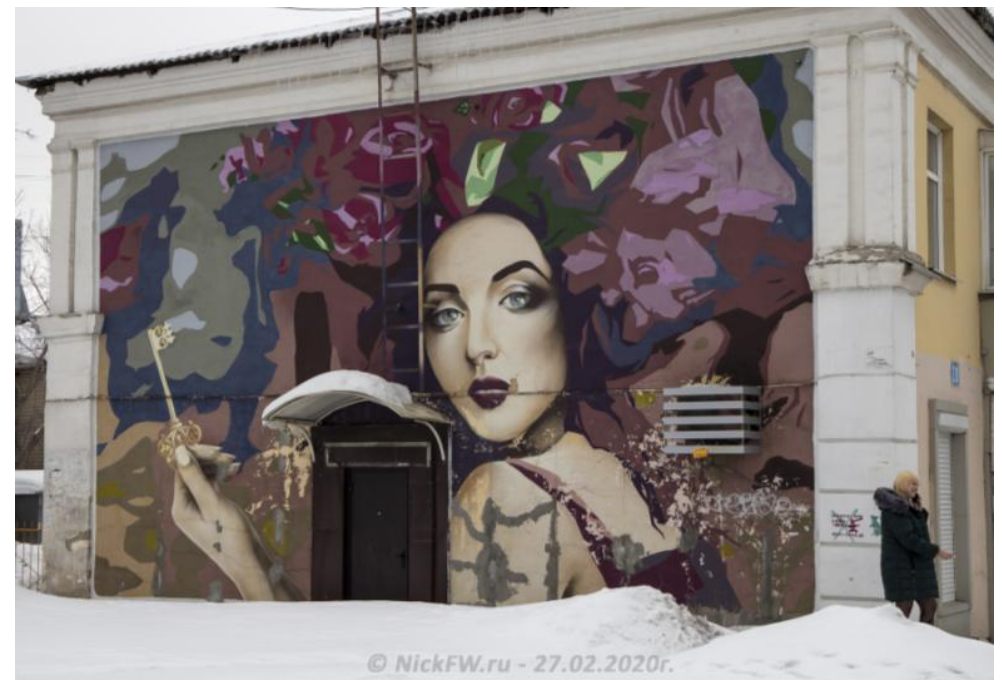

Figure 6 Portret mural in Kemerovo, Lenina av.20 @ NickFW.ru - 27.02.2020г.

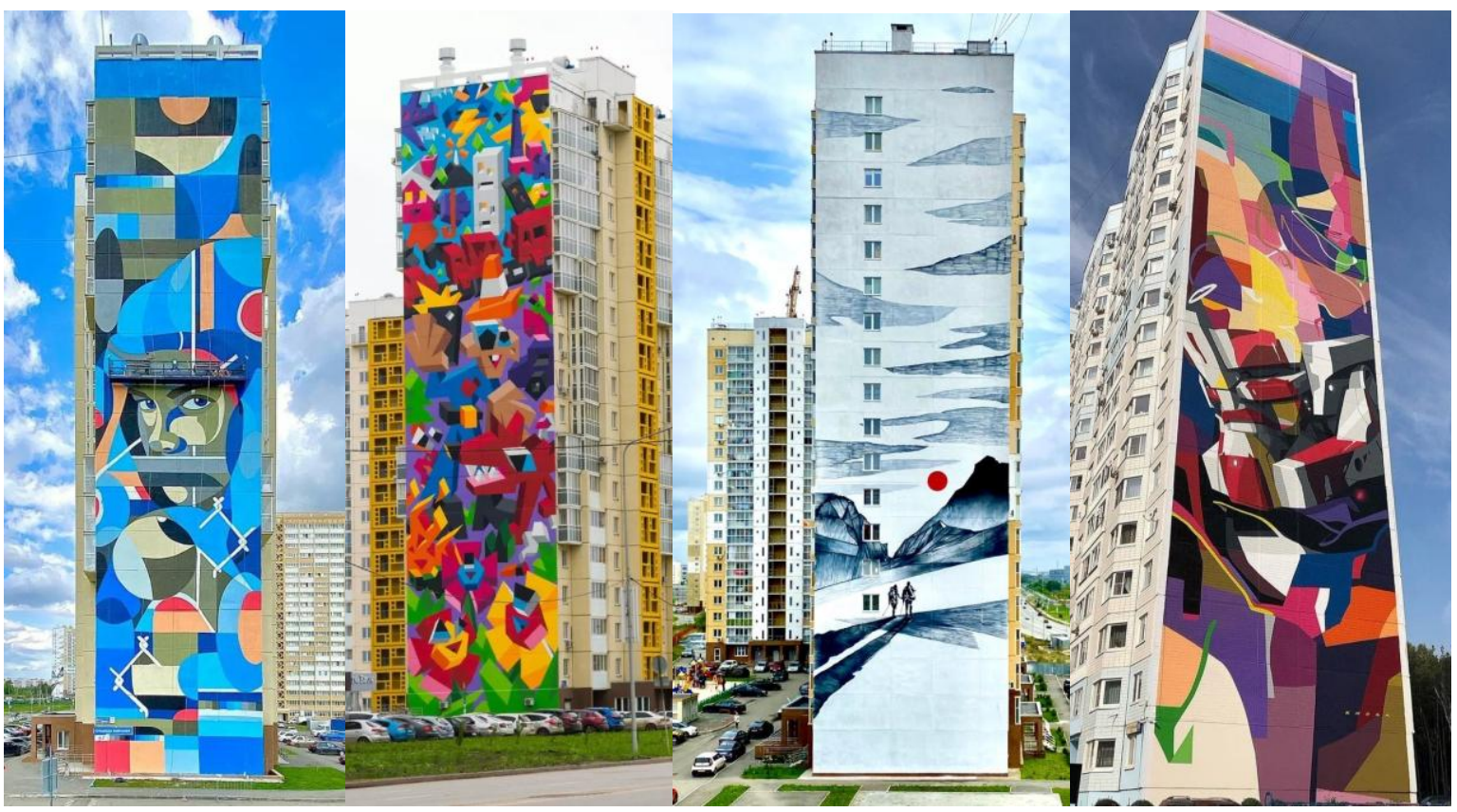

Figure 7 Russian artists works by P.Orez, I. Robe, Vitaly SY, K.Zmogk in street-art festival in Chekyabinsk and Odintzovo, Russia, 2020.

Former industrial zones, transformed into modern business parks, are a favorite urban format for Anatoly Akue (Anatoly Atochkin). His work in the Moscow space of the Kutuzovsky 36 business Park is a series of complex abstract multicolored murals with a total area of about 2000 sq. m. (2019, Moscow, Russia) [12].

\section{STREET ART AND MURALS IN DIALOGUE WITH THE AUTHORITIES: FEATURES OF RUSSIAN PRACTICE}

Russian reality is characterized by a strong administrative factor on the implementation of certain artistic initiatives in the public space. The need for multi-stage coordination with the authorities of most street art practices makes this kind of contemporary art in Russia even less politicized and acute than in other countries. At the 
same time, numerous murals, often very positively appreciated by local residents, look particularly spectacular. Customers of large-scale paintings in the urban space can be building owners or developers, counting on additional advertising and changing the image of specific urban areas.

The negative side of this approach is that most officials, interacting with artists and ultimately determining the possibility of implementing a street art project, have neither professional artistic nor specialized management education in the field of art. Therefore, most interesting works in the genre of street art appear in Russia as a result of a happy coincidence, and not as a result of purposeful programs of development of contemporary art. Of course, there are always positive exceptions to the general rule. And some positive examples of joint

projects of artists, gallerists and city authorities form a more positive attitude to street art in the public consciousness.

In general, there are quite a lot of private initiatives in Russia today, supported by individual museums with enthusiasts promoting contemporary art, individual foundations and public organizations. At the federal level, the so-called "graffiti law" has been adopted, regulating many issues of relations between street artists, the state and society. [13]. But in its current form, the law does not cover all the emerging conflicts of relations of interested parties, and the fate of many works of street art remains uncertain, and the prospects for the development of this direction in art in the space of Russian cities remains vague. ("Figure 8", "Figure 9")

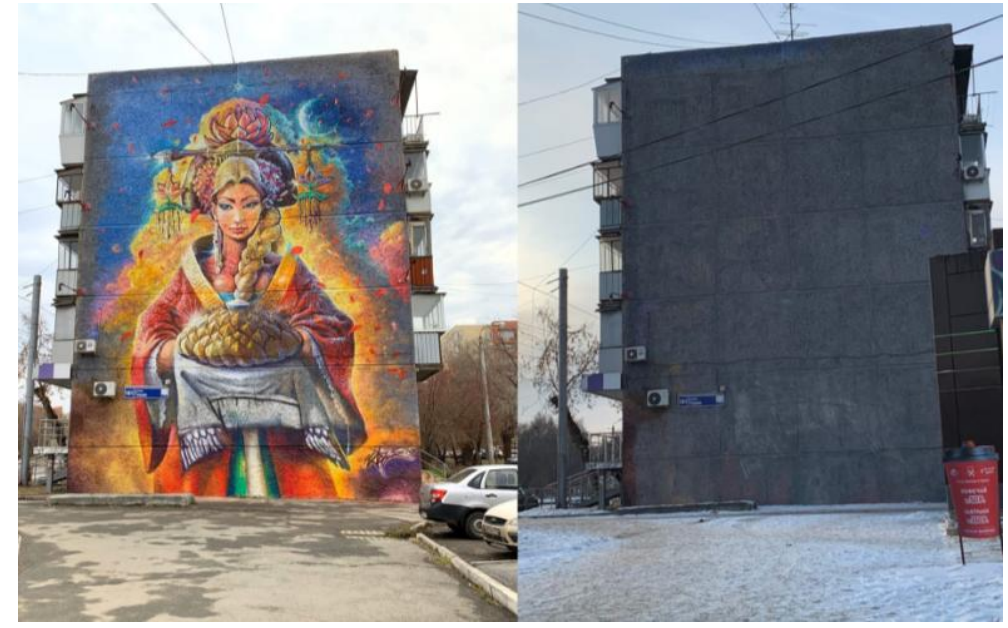

Figure 8 Removal of the V.Odegov's mural after the festival in Chelyabinsk 2021.



Figure 9 Street-art festival in Odintzovo, Moscow region 2020 [14].

\section{CONCLUSION}

The notable presence of street art practices in the open spaces of Russian cities is an accomplished fact. And the abundance of artists recognized in the international artistic environment is a testament to the rooting of the street art subculture in modern Russian reality. However, the 
perception of street art in Russian society is very ambiguous. For some, individual manifestations of street art - social protest, for some - an attempt to humanize the dull urban environment. Some consider the agreed large-scale murals as a tribute to the current world artistic trends, and for some they are a continuation of the traditions of monumental art of late Soviet modernism.

A feature of street art, regardless of its scale, is a sincere expression of its emotions, a certain simplicity of the author's statement, which easily resonates with an outside observer. Street art creates the illusion that understanding of such art does not require any preparation, it is public and therefore attractive. Perhaps this explains the phenomenon of such a wide spread of street art around the world. Taking all new techniques into the framework of its artistic language, street art remains naive and open to any viewer. And the space of the modern city willingly adds color interventions of street art and large-scale murals to the arsenal of its imagery, forming the face of the city of the XXI century in a new way.

\section{AUTHORS' CONTRIBUTIONS}

This paper is independently completed by Marianna Maevskaya.

\section{REFERENCES}

[1] Simon Armstrong. Street art. -M.:Ad Marginem Press, ABC Design, 2019, 176 p. 5,12 [in Russian].

[2] Simon Armstrong. Street art. -M.:Ad Marginem Press, ABC Design, 2019, 176 p. 16 [in Russian].

[3] Claudia Velde. Street art. Monumentalnaya nastennaya zhivopis// Claudia Velde. Street art. Monumental wall painting. - M.:, Art 21st Century, 2018, ISBN 978-5-98051-182-1, page 41

[4] Festival "ART-Ovrag 2013" http://street-artovrag.ru/?cat $=0$ [in Russian]. accessed: 26.06.2021

[5] Encyclopedia rossiyskogo ulichnogo iskusstva. // Encyclopedia of Russian street art. Edited by D. Aske and I.Ponosov. On the rights of the manuscript. 2018,312 c.: p.212 [in Russian].
[6] Claudia Velde. Street art. Monumental wall painting. - M.: Art 21st Century, 2018, ISBN 978-5-98051-182-1, page 18-19 [in Russian].

[7] Pokras Lampas https://ru.wikipedia.org/wiki/\%D0\%9B\%D0\% B0\%D0\%BC\%D0\%BF\%D0\%B0\%D1\%81, $\% \mathrm{D} 0 \% 9 \mathrm{~F} \% \mathrm{D} 0 \% \mathrm{BE} \% \mathrm{D} 0 \% \mathrm{BA} \% \mathrm{D} 1 \% 80 \% \mathrm{D} 0$ $\%$ B0\%D1\%81 accessed: 29.06.2021

[8] Encyclopedia rossiyskogo ulichnogo iskusstva. // Encyclopedia of Russian street art. Edited by D. Aske and I.Ponosov. On the rights of the manuscript. 2018, 312 c.: p. 179 [in Russian].

[9] Groyse, Boris. Publichnoe prostranstvo: ot pustoty k paradoksu. //STRELKA: Sbornik 2013. - M.: Strelka Press, 2013. "Public space: From emptiness to paradox".... Collection Strelka Press p. 12-15

[10] Encyclopedia rossiyskogo ulichnogo iskusstva. // Encyclopedia of Russian street art. Edited by D. Aske and I.Ponosov. On the rights of the manuscript. 2018, 312 c.: p. 194, 216-217 [in Russian].

[11] Samuy interesny street art v Moskve 2020 //"The most interesting street-art in Moscow 2020"

http://moscowwalks.ru/2021/02/25/beststreeta rt-2020/ accessed: 25.06.2021

[12] Samuy interesny street art v Moskve 2020 //"The most interesting street-art in Moscow $2020 "$. http://moscowwalks.ru/2021/02/25/beststreeta rt-2020/ accessed: 25.06.2021

[13] https://duma.mos.ru/ru/37/news/novosti/novyi y-stolichnyiy-zakon-reglamentiruet-naneseniei-udalenie-s-gorodskih-sten-graffiti accessed: 29.06.2021

[14] Festival "urban morphogenesis" v Odintzovo// Festival "urban morphogenesis" in Odintzovo. https://vivacity.ru/graffiti/video/festivalurban-morphogenesis/ accessed: 29.06.2021 